\title{
Effects of a two-year health-enhancing physical activity program on skeletal muscle protein profiles in people with rheumatoid arthritis
}

\author{
Elena Ossipova \\ Karolinska Institutet \\ Helena Idborg \\ Karolinska Institutet \\ Cecilia Fridén \\ Karolinska Institutet \\ Per-Johan Jakobsson \\ Karolinska Institutet \\ Eva Kosek \\ Karolinska Institutet \\ Christer Malm \\ Umea Universitet \\ Birgitta Nordgren \\ Karolinska Institutet \\ Christina Opava \\ Karolinska Institutet \\ Yelverton Tegner \\ Lulea Tekniska Universitet \\ Jone Vanluyten \\ Karolinska Institutet \\ Marina Korotkova \\ Karolinska Institutet \\ Ingrid Lundberg ( $\square$ Ingrid.Lundberg@ki.se) \\ Karolinska Institutet https://orcid.org/0000-0002-6068-9212
}

Research article

Keywords: exercise, muscle, quantitative proteomics, rheumatoid arthritis

Posted Date: August 18th, 2020

DOI: https://doi.org/10.21203/rs.3.rs-46096/v1

License: (c) (i) This work is licensed under a Creative Commons Attribution 4.0 International License. Read Full License 


\section{Abstract \\ Background}

Rheumatoid arthritis (RA) induces loss of muscle mass and impairments, which discourage physical activity. Consequently, RA is associated with decreased levels of exercise. Positive effects of exercise on physical and mental health without increasing pain or disease activity have been demonstrated but the influence of moderate-intensity physical activity on the molecular effects in skeletal muscle in people with RA remains unclear. In this pilot study we investigated the impact of a two-year health-enhancing physical activity (HEPA) program on protein profiles in skeletal muscle biopsies from people with RA based on a unique set of interdisciplinary variables.

\section{Methods}

Six people with RA participated. Muscle biopsies were taken from $m$. vastus lateralis, and perceived disease impact, anthropometrics and physical capacity tests were assessed at baseline and year 1 and 2 . Mass spectrometry-based quantitative proteomics and immunohistochemistry analysis were employed to examine molecular changes in the skeletal muscle in response to long-term HEPA.

\section{Results}

The study participants had moderate to low adherence to the HEPA program, the perceived disease impact and anthropometric parameters were not altered. Among the physical capacity tests, the Timed-stands test showed a significant improvement after one year. Mean pressure pain threshold was significantly reduced after 1-and 2-year HEPA participation. Proteome analysis of the muscle biopsies showed an up-regulation of proteins in the mitochondrial respiratory chain and predicted increased ATP production and improved muscle contractility in response to HEPA. Molecular pathways identified by proteome analysis revealed correlations to pain variables.

\section{Conclusions}

Our results indicate that long-term physical activity in people with RA may up-regulate proteins in the mitochondrial respiratory chain predicting increased ATP production and muscle contractility similar to what has been reported in healthy young men and might have a positive impact on muscle tissue by decreased muscle cell death.

\section{Background}

Planned and structured exercise has long been recommended to people with rheumatoid arthritis (RA) in order to prevent or reduce disability that may partly be attributed to a vicious circle of systemic and local inflammation, muscle wasting and reduced levels of physical activity ${ }^{1}$. More recently, the value of exercise to reduce risk factors for cardiovascular disease that are associated with RA has been recognized ${ }^{2-3}$. Public health recommendations for health-enhancing physical activity (HEPA) to reduce cardiovascular disease risk include at least 30 minutes of daily, at least moderate-intensity, physical activity and, in addition, twice weekly strength training ${ }^{4-5}$. HEPA in an everyday environment has also proven to be beneficial in people with $\mathrm{RA}^{6-7}$. However, whether HEPA affects molecular pathways in muscle tissue behind systemic effects to the same extent as supervised high-intensity exercise is largely unknown.

A recent study revealed broad-ranging molecular alterations regarding pro-inflammatory markers, transcriptional profiles and metabolic signatures in skeletal muscle of people with RA compared to matched healthy individuals ${ }^{8}$. Furthermore, disease activity, disability and physical inactivity in people with RA were associated with altered levels of the muscle pro-inflammatory mediators and metabolic intermediates. Also, oxidative stress induced modifications in actin and promoted muscle weakness in people with RA by breaking actin filament stability and disrupting myosin interactions ${ }^{9}$.

Our group has reported that endurance exercise affects molecular pathways that regulate inflammation, aerobic capacity, capillary growth and remodelling of skeletal muscle in patients with polymyositis and dermatomyositis ${ }^{10}$. Whether inflammatory signalling and dysregulated remodelling in skeletal muscle in RA may be mitigated by combining pharmacological treatment with physical activity over a long period of time is not known.

A two-year program of Physical Activity in RA (PARA) 2010 was designed to investigate its feasibility and to study changes in self-reported variables, physical capacity measurements, inflammation, pain modulation and cardiovascular risk ${ }^{11}$. Positive changes during the two-year study period were observed for HEPA participants concerning symptoms and physical capacity ${ }^{12-13}$ and cardiovascular risk factors ${ }^{14-15}$, while pain modulation did not change ${ }^{16}$. In this context we performed a pilot study with focus on protein adaptations in muscle tissue in a subgroup of 
people with RA who consented to repeated muscle biopsies. The aim of the present study was to investigate potential changes in protein expression patterns in response to a two-year HEPA program applying proteomic analysis in repeated skeletal muscle biopsies in relation to clinical variables in a subgroup of patients from the PARA 2010 study.

\section{Materials And Methods Participants and samples}

Participants in the PARA 2010 study were recruited from the Swedish Rheumatology Quality registers (SRQ). They were asked to participate in a two-year program aimed to increase and maintain HEPA levels among people with RA in line with public health recommendations ${ }^{11-13}$

For this sub-study six women who consented to donate muscle biopsies at baseline, at one- and two-year follow-ups were included. The participants were independent in daily living, interested in physical activity support, fluent in Swedish, not already obtaining HEPA as per recommendations and without major diseases preventing HEPA ${ }^{11}$. The median age was 64.5 (range 54-73) years and median disease duration 6.5 (range 3-20) years. Information about disease activity, physical activity and treatment is displayed in Table 1.

Skeletal muscle biopsies and blood samples were collected at Karolinska University Hospital, Stockholm, Sweden and at Sunderbyn Hospital, Luleå, Sweden. Ethical approval was obtained from Stockholm Regional Research Ethics Committee (2010/1232-31/1). Each participant gave written informed consent to participate in the study.

\section{HEPA program}

The support program aimed at adoption and maintenance of HEPA according to recommendations ${ }^{4}$.

The program consisted of three parts: moderate-intensity physical activity, strength training at public gyms, and bi-weekly support group meetings based on behaviour change theory ${ }^{17}$. Participants were expected to perform both the moderate-intensity physical activity and the gym training as part of their daily life at times that were convenient to them ${ }^{11}$.

At the start a physiotherapist, specialised in rheumatology, gave instructions and set up HEPA programs tailored to each participant's capacity. Thereafter physiotherapists were available for consultations in the gym for one hour weekly. Biweekly, one-hour support group meetings were organized by physiotherapists in order to educate, give feedback and improve the participants' self-efficacy for HEPA. Groups consisted of 5-10 persons and focused on how to incorporate and maintain HEPA in their daily schedule based on the Transtheoretical Model of Change (TTM) ${ }^{18}$. These gatherings were also important occasions to share experiences and enable social support, in accordance with the social cognitive theory $(\mathrm{SCT})^{17}$. All participants received a pedometer and free access to a website (www.keepwalking.se) to monitor and stimulate physical activity. During the second year the participants maintained the individualized HEPA programs, without physiotherapist support and support group meetings were optional. More information about the HEPA program is described by Nordgren et al. ${ }^{11}$.

\section{Clinical assessments}

Disease Activity Score 28 (DAS 28) ${ }^{19}$, Rheumatoid Factor (RF)/Anti-Citrullinated Protein Antibody (ACPA) positivity, C-Reactive Protein (CRP) and Erythrocyte Sedimentation Rate (ESR) and information on drug treatment were retrieved from the SRQ and patient records.

Data from self-reported questionnaires and physiotherapy assessments were collected before starting the HEPA program, after one and two years and included:

- Self-reports on perceived disease impact measured by a visual analog scale (VAS, 0-100), pain measured by a VAS (0-100), fatigue measured by a VAS (0-100), health-related quality of life measured with the EuroQol five-dimension (EQ-5D) thermometer (0-100) ${ }^{20}$ and activity limitation assessed with the Health Assessment Questionnaire (HAQ, 0-3) ${ }^{20}$.

- Assessments of body mass index (BMI), waist circumference, and blood pressure.

- Tests of physical capacity including maximal aerobic capacity $\left(\mathrm{VO}_{2 \mathrm{max}}\right)$ estimated from a submaximal bicycle ergometer test ${ }^{21}$, lower limb function with the Timed-Stands Test (TST) ${ }^{22}$, maximum and average grip strength with the Grippit device ${ }^{23}$ and maximum voluntary contraction force (MVC) of the right knee extensors using a Biodex Multi-Joint System 4 Pro dynamometer were collected by physiotherapists.

Sensitivity to pressure pain was evaluated using pressure algometry ${ }^{24}$. Global pain intensity was rated on a visual analogue scale (VAS, range 0 100) before pressure pain thresholds (PPTs) were assessed bilaterally at three sites (mm.supraspinatus, mm.gluteus maximus and the lateral 
epicondyles). The mean of the stimulus intensity ( $\mathrm{kPa}$ ) of the six sites was calculated for each participant and used as the individual PPT mean $^{24}$. Suprathreshold pressure pain sensitivity (SPPS) was assessed the same six sites. The participants were asked to indicate when the pressure reached an intensity rated as $4 / 10$ and $7 / 10$, respectively on the Borg CR-10 scale 24 .

Adherence to the HEPA program assessed by two weekly text messages; one on the number of circuit training sessions performed in the past week and the other on the number of additional days with physical activity performed on at least a moderate intensity level for $\geq 30$ minutes ${ }^{25}$. The total number of days with circuit training and/or moderate-intensity physical activity is reported.

\section{Muscle biopsies}

Eighteen muscle biopsies were collected from six participants at the annual physical exams (before start of the exercise program, after one and two years). Muscle tissue biopsies were obtained from $m$. vastus lateralis under local anaesthesia using the semi open biopsy technique ${ }^{26}$. Muscle biopsies were snap frozen in isopentane and stored in the freezer at -80C.

\section{Mass spectrometry-based proteomics}

Muscle biopsies were sectioned in the cryostat and mounted with SDS lysis buffer (4\% SDS, 25 mM HEPES pH 7.6 and $1 \mathrm{mM}$ DTT purchased from Sigma-Aldrich). Samples of approximately $200 \mu$ with a tissue: buffer ratio of $1: 5(v / v)$ were heated for 5 minutes at $95^{\circ} \mathrm{C}$, sonicated $(3 \times 20$ $\mathrm{s}$, power 45\%), clarified by centrifugation at $14000 \mathrm{~g}$ for $15 \mathrm{~min}$ and the pellet was discarded. The protein concentration of each remaining supernatant was measured with a BCA-kit (Pierce).

Protein samples of $200 \mu \mathrm{g}$ were dissolved in $8 \mathrm{M}$ urea, $1 \mathrm{mM}$ DTT and $25 \mathrm{mM}$ HEPES pH 7.6 and prepared as described elsewhere ${ }^{27}$. After protein digestion the peptide concentration was determined using a BCA-kit. A pooled internal standard was prepared by combining equal peptide amount from ten samples. Equal amount of protein digests $(70 \mu \mathrm{g})$ from each sample suspended in $0.1 \mathrm{M}$ triethyl ammonium bicarbonate buffer (Sigma-Aldrich) were labelled with Tandem Mass Tag (TMT) 10-plex Isobaric Mass Tagging Kit (ThermoFisher Scientific) according to the manufacturer's instructions. Labelled samples were dissolved in loading buffer ( $3 \% \mathrm{ACN}, 0.1 \% \mathrm{FA})$, resulting in a final concentration of $10 \mu \mathrm{g} / \mu \mathrm{l}$ prior the liquid chromatography mass spectrometry (LC-MS/MS) analysis.

LC-MS/MS was performed on a hybrid Q-Exactive mass spectrometer (ThermoFisher Scientific). Peptides were trapped on Acclaim PepMap trap column (C18, $3 \mu \mathrm{m}, 100 \AA, 75 \mu \mathrm{m} \times 20 \mathrm{~mm})$, and separated on an Acclaim PepMap RSLC column (C18, $2 \mu \mathrm{m}, 100 \AA, 75 \mu \mathrm{m} \times 50 \mathrm{~cm})$, (ThermoFisher Scientific) using a gradient of $A(5 \%$ DMSO, $0.1 \% \mathrm{FA})$ and B ( $90 \% \mathrm{ACN}, 5 \% \mathrm{DMSO}, 0.1 \% \mathrm{FA})$, ranging from $3 \%$ to $37 \% \mathrm{~B}$ in $240 \mathrm{~min}$ with a flow of $0.25 \mu \mathrm{l} / \mathrm{min}$.

The top 10 ions were selected with Fourier Transform Mass Spectrometry (FTMS) and the survey scan was performed at 70.000 resolution from 400-1600 m/z, with a max injection time of $140 \mathrm{~ms}$ and target of $1 \times 10^{6}$ ions. For generation of HCD fragmentation spectra, a max ion injection time of $150 \mathrm{~ms}$ and AGC of $1 \times 10^{5}$ were used before fragmentation at $30 \%$ normalized collision energy, 35.000 resolution. Precursors were isolated with a width of $2 \mathrm{~m} / z$ and put on the exclusion list for $70 \mathrm{~s}$. Single and unassigned charge states were rejected from precursor selection.

\section{Data analysis}

Acquired MS raw files were analysed with Proteome Discoverer 1.3 (ThermoFisher Scientific) and peak lists were searched using Sequest algorithm against the UniProtKB/SwissProt human database (containing 42163 canonical and isoform sequences, 2019-09-24) and filtered to a $1 \%$ FDR using Percolator. Precursor mass tolerance was set to $10 \mathrm{ppm}$ and fragments mass tolerance was set to $0.02 \mathrm{Da}$ for HCD-FTMS. The search algorithm assessed tryptic peptides with maximum 1 missed cleavage; carbamidomethylation (C) and TMT 10-plex (K, N-term) were set as fixed modifications and oxidation (M) as variable modification. Only unique peptides in the data set were used for quantification, while reporter ions were quantified by Proteome Discoverer on HCD-FTMS tandem mass spectra (integration tolerance 20 ppm).

Biological context and molecular networks were analysed using PANTHER Classification System and Ingenuity Pathway Analysis (IPA; Ingenuity Systems, www.ingenuity.com).

Partial least squares discriminant analysis (PLS-DA) on proteomics data and eight clinical variables (TST, MVC, Pain, PPTmean, Suprathreshold4/10, Suprathreshold7/10 using SIMCA P+ version 12 (MKS Data Analytics Solution, Umeå, Sweden) was performed. Comparisons were made between baseline and year one, and between baseline and year two.

\section{Immunohistochemistry staining}


Cryostat sections $(7 \mu \mathrm{m})$ of the muscle biopsies were fixed in $2 \%$ formaldehyde-PBS solution washed in PBS and stored in the freezer at $-80^{\circ} \mathrm{C}$. Staining of cryosections to detect endothelial cells with monoclonal mouse antibodies anti-CD31 (clone EN4, Monosan, Uden, Netherlands) and anti-CD34 (clone QBend/10, BioGenex, The Hague, Netherlands) was performed according to a standard protocol ${ }^{28}$. Isotype-matched irrelevant antibody was used as negative control (clone DAK-G01, Dako, Glostrup, Denmark). Stained sections were analysed with a Polyvar II microscope (Reichert-Jung, Vienna, Austria) and photographed with a digital Leica camera 300F (Leica, Cambridge, UK) (Figure 4). CD31 and CD34 positively stained capillaries were counted with the Quantimet 600 image analyser (Leica) and the results were expressed as numbers of capillaries per area $\left(\mathrm{mm}^{2}\right)$ reflecting the capillary density.

\section{Statistical Analysis}

Statistical analysis of self-reports, physical capacity, PPTs and HEPA was performed with STAT View for Windows (version 5.0.1.0; SAS Institute Inc). Data were analysed with non-parametric Wilcoxon's signed rank test. P-values $<0.05$ were considered statistically significant. Quantitative proteomics data was analysed by paired T-test in order to investigate the significance of the difference in expression between the base level and year one or two. Clinical outcome measures were correlated to the results of the muscle proteome analysis applying Pearson's test. In IPA, the activation z-score, an indication for an activated/inhibited status of certain transcription regulators or processes was calculated on the basis of experimentally observed protein levels and findings in current literature. Associations between proteins and pathways or functions were calculated with a right-tailed Fisher exact test $(p<0.05)$.

\section{Results}

\section{Clinical data}

The achieved frequency of HEPA recorded for the participants was an average of 287 days during the first year, and 179 days for the second year (Table 1). TST improved significantly compared to baseline after one year but was not sustained at two-year assessments (Table 2). Generally, perceived disease impact, pain, fatigue, health-related quality of life and activity limitation did not change from baseline to one- or two-year follow-ups, neither did $\mathrm{BMI}$, waist circumference or blood pressure. No changes in $\mathrm{VO}_{2 \mathrm{max}}, \mathrm{MVC}$ of the knee extensor or grip strength when compared to baseline were recorded. Among the pain-related variables, the mean PPT was significantly reduced after one and two years while SPPS was significantly decreased after one year (Table 2). 
Table 1

Descriptive participant characteristics

\begin{tabular}{|c|c|c|c|c|c|c|c|c|c|c|c|}
\hline \multirow[t]{2}{*}{ Participant } & \multirow{2}{*}{$\begin{array}{l}\text { Age at } \\
\text { HEPA } \\
\text { program } \\
\text { start }\end{array}$} & \multirow{2}{*}{$\begin{array}{l}\text { Disease } \\
\text { duration, } \\
\text { years }\end{array}$} & \multirow[t]{2}{*}{ Year } & \multirow{2}{*}{$\begin{array}{l}\text { DAS28, } \\
0-28\end{array}$} & \multirow{2}{*}{$\begin{array}{l}\text { RF/ACPA, } \\
+/-\end{array}$} & \multirow{2}{*}{$\begin{array}{l}\text { CRP, } \\
\mathrm{mg} / \mathrm{l}\end{array}$} & \multirow{2}{*}{$\begin{array}{l}\text { ESR, } \\
\mathrm{mm} / \mathrm{h}\end{array}$} & \multicolumn{4}{|l|}{ Medication } \\
\hline & & & & & & & & Biological & $\begin{array}{l}\text { DMARD, } \\
\text { mg }\end{array}$ & NSAID & $\mathrm{GS}, \mathrm{mg}$ \\
\hline \multirow[t]{3}{*}{1} & \multirow[t]{3}{*}{64} & \multirow[t]{3}{*}{14} & 0 & NA & RF+/ACPA+ & 4.2 & 28 & NA & NA & NA & no \\
\hline & & & 1 & NA & & 6.3 & 26 & NA & $\begin{array}{l}\text { MTX } \\
15\end{array}$ & NA & no \\
\hline & & & 2 & 3.84 & & 3.6 & 27 & Adalimumab & $\begin{array}{l}\text { MTX } \\
15\end{array}$ & yes & no \\
\hline \multirow[t]{3}{*}{2} & \multirow[t]{3}{*}{64} & \multirow[t]{3}{*}{20} & 0 & 3.05 & $\begin{array}{l}\text { RF-/ACPA } \\
\text { NA }\end{array}$ & 14.2 & 16 & Adalimumab & $\begin{array}{l}\text { MTX, } \\
20\end{array}$ & yes & no \\
\hline & & & 1 & NA & & 15.4 & 10 & Adalimumab & $\begin{array}{l}\text { MTX, } \\
20\end{array}$ & yes & no \\
\hline & & & 2 & 3.6 & & 8.5 & 19 & Adalimumab & $\begin{array}{l}\text { MTX, } \\
20\end{array}$ & yes & $\begin{array}{l}\text { Prednisolone, } \\
2.5\end{array}$ \\
\hline \multirow[t]{3}{*}{3} & \multirow[t]{3}{*}{72} & \multirow[t]{3}{*}{5} & 0 & NA & RF-/ACPA- & 4.7 & NA & NA & no & no & no \\
\hline & & & 1 & NA & & 4.1 & NA & NA & no & no & no \\
\hline & & & 2 & NA & & 4.8 & NA & NA & no & no & no \\
\hline \multirow[t]{3}{*}{4} & \multirow[t]{3}{*}{54} & \multirow[t]{3}{*}{8} & 0 & 2.27 & RF+/ACPA+ & 0.95 & 9 & no & $\begin{array}{l}\text { MTX } \\
15\end{array}$ & no & no \\
\hline & & & 1 & 1.72 & & 1.2 & NA & no & $\begin{array}{l}\text { MTX } \\
15\end{array}$ & no & no \\
\hline & & & 2 & 1.75 & & 1.2 & 7 & no & $\begin{array}{l}\text { MTX } \\
15\end{array}$ & yes & no \\
\hline \multirow[t]{3}{*}{5} & \multirow[t]{3}{*}{73} & \multirow[t]{3}{*}{3} & 0 & 2.49 & RF-/ACPA- & 0.41 & 20 & no & $\begin{array}{l}\text { MTX } \\
15\end{array}$ & yes & $\begin{array}{l}\text { Prednisolone, } \\
3.75\end{array}$ \\
\hline & & & 1 & 3.51 & & 0.69 & 17 & no & $\begin{array}{l}\text { MTX } \\
15\end{array}$ & yes & $\begin{array}{l}\text { Prednisolone, } \\
3.75\end{array}$ \\
\hline & & & 2 & 2.39 & & 1.1 & 23 & no & $\begin{array}{l}\text { MTX } \\
15\end{array}$ & NA & $\begin{array}{l}\text { Prednisolone, } \\
2.5\end{array}$ \\
\hline \multirow[t]{3}{*}{6} & \multirow[t]{3}{*}{65} & \multirow[t]{3}{*}{4} & 0 & 1.69 & RF-/ACPA- & 0.54 & 11 & Adalimumab & $\begin{array}{l}\text { MTX, } \\
20\end{array}$ & yes & no \\
\hline & & & 1 & 1.53 & & 3.1 & 8 & Adalimumab & $\begin{array}{l}\text { MTX, } \\
20\end{array}$ & yes & no \\
\hline & & & 2 & 1.13 & & 1.1 & 5 & Adalimumab & $\begin{array}{l}\text { MTX, } \\
20\end{array}$ & yes & NA \\
\hline
\end{tabular}


Table 2

Self-reports, anthropometrics, physical capacity and pain-related measurements of participants with RA at baseline and after 1 year or 2 years HEPA-program.

\begin{tabular}{|c|c|c|c|}
\hline & $\begin{array}{l}\text { Baseline } \\
\text { Median (range) }\end{array}$ & $\begin{array}{l}1 \text { year } \\
\text { Median (range) }\end{array}$ & $\begin{array}{l}2 \text { year } \\
\text { Median (range) }\end{array}$ \\
\hline \multicolumn{4}{|l|}{ Self-reports } \\
\hline HEPA days total, $n$ & 0 & $290(205-338)$ & $194(29-323)$ \\
\hline Percieved disease impact, VAS (0-100) & $17(4-53)$ & $39(1-79)$ & $30(1-80)$ \\
\hline Pain, VAS (0-100) & $15.5(2-57)$ & $21(1-68)$ & $42(1-85)$ \\
\hline Fatigue, VAS (0-100) & $25(6-56)$ & $25.5(1-71)$ & $52(0-85)$ \\
\hline Health-related quality of life, EQ-5D thermometer $(0-100)$ & $76(70-85)$ & $75(50-95)$ & $60(50-100)$ \\
\hline Activity limitation, HAQ (0-3) & $0.25(0-1)$ & $0.63(0.75)$ & $0.125(0-1.125)$ \\
\hline \multicolumn{4}{|l|}{ Anthropometrics } \\
\hline $\mathrm{BMI}, \mathrm{kg} / \mathrm{m}^{2}$ & $27.7(22.4-32.4)$ & $27.6(23-29.7)$ & $26.9(22.8-29.7)$ \\
\hline Waist circumference, cm & $89(79-105)$ & $87(77-99)$ & $86(77-102)$ \\
\hline Systolic blood pressure, $\mathrm{mmHg}$ & $129(111-143)$ & $132(121-144)$ & $135(112-146)$ \\
\hline Diastolic blood pressure, $\mathrm{mmHg}$ & $77(63-96)$ & $84(77-88)$ & $82(68-85)$ \\
\hline \multicolumn{4}{|l|}{ Physical capacity } \\
\hline \multicolumn{4}{|l|}{ Estimated $\mathrm{VO}_{2 \max }, \mathrm{I} / \mathrm{min}$} \\
\hline \multicolumn{4}{|l|}{ Estimated $\mathrm{VO}_{2 \max }, \mathrm{ml} / \mathrm{kg} / \mathrm{min}$} \\
\hline $\begin{array}{l}\text { Lower limb function, } \\
\text { Timed-stands (TST), s }\end{array}$ & $21(17-31)$ & $16(14-24) *$ & $17(12-22)$ \\
\hline Grip strength, max, N & $244(100-298)$ & $238(99-302)$ & $220(91-291)$ \\
\hline Grip strength, average, N & $200(85-271)$ & $211(85-255)$ & $182(74-255)$ \\
\hline Knee extensor strength, $\mathrm{Nm}$ & $93(78-105)$ & $100(68-127)$ & $93(77-129)$ \\
\hline \multicolumn{4}{|l|}{ Pain-related variables } \\
\hline Pain, (VAS), 0-100 & $12(0-23)$ & $15(1-75)$ & $12(1-21)$ \\
\hline PPT mean, kPa & $321(259-578)$ & $195(150-476) \star$ & $206(175-331) *$ \\
\hline SPPS 4/10 mean, $\mathrm{kPa}$ & $463(316-894)$ & $35(206-554)$ & $351(287-646)$ \\
\hline SPPS 7/10 mean, kPa & $709(446-1398)$ & $462(323-653) \star$ & $585(452-830)$ \\
\hline
\end{tabular}

HEPA = Health-Enhancing Physicl Activity; VAS = Visual Analog Scale; BMI = body mass index; EQ5D = EuroQol five-dimension; HAQ = Health Assessment Questionnaire disability index; MVC = Maximum Voluntary Contraction force; PPT = Pressure Pain Threshold; SPPS = Suprathreshold Pressure Pain Sensitivity.

$\star, p<0.05$.

\section{Muscle Biopsy Data- Capillary Density}

Capillary density in skeletal muscle was investigated using immunohistochemistry. The mean density of CD31 and CD34-positive capillaries was not significantly altered after one or two-year following the HEPA program (Supplementary Fig. 1A and 1B). 


\section{Proteome profiles in repeated muscle biopsies}

Changes in protein expression in skeletal muscle after endurance exercise were monitored using mass spectrometry based proteomics. Proteome profiles of skeletal muscle biopsies resulted in quantification of 962 proteins in the samples obtained at years zero, one and two. Multivariate statistics applied for the analysis of obtained proteomics data demonstrated separation between muscle biopsies proteomes of patients at zero, one and two years (Supplementary Figure 2). The protein levels for the follow-up years were compared to the patient's own values in the biopsy taken before the intervention (year zero). Eight proteins were significantly $(p<0.05)$ altered after one year of the HEPA program (five up- and three down-regulated) (Table 3). After two years of the HEPA program 21 proteins were significantly altered $(p<0.05)(18$ proteins were up- and three proteins down-regulated) compared to the baseline level (Table 4). Data analysis also revealed up-regulation of the ATP synthase alpha protein $(p<0,05)$, and at the same time, in five participants out of six the protein mitochondrial ATPase inhibitor (IF1) was reduced but did not reach statistical significance at group level. Moreover, we found that the protein, Carnitine Palmitoyltransferase 1B (CPT1B) involved in fatty acid betaoxidation pathway in muscle mitochondria, was significantly up-regulated while the protein Otubain-1 (OTUB1) involved in mitochondrial apoptosis was significantly lower both after one year and two years of the HEPA program.

Table 3. Proteins significantly altered in muscle tissue after one year HEPA program.

\begin{tabular}{|c|c|c|c|}
\hline Gene & Protein name & $\begin{array}{l}\text { Fold } \\
\text { change }\end{array}$ & Protein function \\
\hline cox7C & Cytochrome c oxidase subunit $7 \mathrm{C}$, mitochondrial & 1.52 & $\begin{array}{l}\text { Terminal component of the mitochondrial } \\
\text { respiratory chain }\end{array}$ \\
\hline COX8A & Cytochrome c oxidase subunit $8 \mathrm{~A}$, mitochondrial & 1.49 & Terminal enzyme of the respiratory chain \\
\hline NDUFS7 & $\begin{array}{l}\text { NADH dehydrogenase [ubiquinone] iron-sulfur protein } \\
7 \text {, mitochondrial }\end{array}$ & 1.33 & $\begin{array}{l}\text { Protein of the complex that forms the } \\
\text { mitochondrial respiratory chain }\end{array}$ \\
\hline IDH3B & $\begin{array}{l}\text { Isoform A of Isocitrate dehydrogenase [NAD] subunit } \\
\text { beta, mitochondrial }\end{array}$ & 1.24 & $\begin{array}{l}\text { Catalyse the allosterically regulated rate-limiting step of the } \\
\text { tricarboxylic acid cycle }\end{array}$ \\
\hline CPT1B & $\begin{array}{l}\text { Isoform } 2 \text { of Carnitine 0-palmitoyltransferase 1, } \\
\text { muscle isoform }\end{array}$ & 1.20 & $\begin{array}{l}\text { Control the long-chain fatty acid beta-oxidation pathway in } \\
\text { muscle mitochondria }\end{array}$ \\
\hline PRDX1 & Peroxiredoxin-1 & -1.12 & $\begin{array}{l}\text { Thiol-specific peroxidase, protective role against oxidative } \\
\text { stress }\end{array}$ \\
\hline OTUB1 & Ubiquitin thioesterase & -1.19 & Cleaves ubiquitin from branched poly-ubiquitin chains \\
\hline RALA & Ras-related protein Ral-A & -1.19 & $\begin{array}{l}\text { GTP-binding proteins which mediate the transmembrane } \\
\text { signaling }\end{array}$ \\
\hline
\end{tabular}

Fold change in comparison to the base level, $p<0.05$.

\section{Gene Ontology Analysis And Pathway Analysis}

Gene ontology (GO) enrichment analysis and Overrepresentation Test using PANTHER Classification System performed on the basis of the whole human genome revealed overrepresentation of the biological processes related to muscle contractility, energy metabolism and mitochondrial function (Fig. 1).

The analysis with IPA indicated that our dataset of proteins was enriched in proteins involved in the following molecular and cellular functions: Cell Death and Survival, Cell Morphology, Free Radical Scavenging, Protein Synthesis and Nucleic Acid Metabolism. The top five canonical pathways involved were Mitochondrial Dysfunction, Oxidative Phosphorylation, Actin Cytoskeleton Signaling, Eukaryotic Initiation Factor 2 (ElF2) Signaling and Acute Phase Response Signaling. Most changes in the follow up biopsies after the HEPA program were seen in the mitochondrial respiratory chain pathway. After the first year of the HEPA program, four out of five up-regulated proteins are involved in the mitochondrial respiratory chain (COX7C, COX8A, NDUFS7 and IDH3B) (Table 3).

After two years of HEPA, eight of 21 the significantly up-regulated proteins are involved in the mitochondrial respiratory chain (CX6B1, NDUFA4, CYC1, NDUA9, NDUA7, ATPA, NDUA2, and ACAA2) (Table 4). 
Table 4

Proteins significantly altered in muscle tissue after two years with the HEPA program.

\begin{tabular}{|c|c|c|c|}
\hline Gene & Protein name & $\begin{array}{l}\text { Fold } \\
\text { change }\end{array}$ & Protein function \\
\hline CX6B1 & Cytochrome $\mathrm{c}$ oxidase subunit 6B1 & 1.34 & Terminal enzyme of the mitochondrial respiratory chain \\
\hline FAM162A & Protein FAM162A & 1.31 & Involved in regulation of apoptosis \\
\hline NDUFA4 & $\begin{array}{l}\text { NADH dehydrogenase [ubiquinone] } 1 \text { alpha subcomplex } \\
\text { subunit } 4\end{array}$ & 1.26 & $\begin{array}{l}\text { Protein of the complex, that forms the mitochondrial } \\
\text { respiratory chain }\end{array}$ \\
\hline CYC1 & Cytochrome $\mathrm{c} 1$, heme protein, mitochondrial & 1.25 & $\begin{array}{l}\text { Transfers electrons to cytochrome } \mathrm{c} \text { in the mitochondria } \\
\text { respiratory chain. }\end{array}$ \\
\hline RPL12 & $60 S$ ribosomal protein L12 & 1.23 & Ribosomal protein \\
\hline NDUFA9 & $\begin{array}{l}\text { NADH dehydrogenase [ubiquinone] } 1 \text { alpha subcomplex } \\
\text { subunit } 9 \text {, mitochondrial }\end{array}$ & 1.21 & $\begin{array}{l}\text { Protein of the complex, that forms the mitochondrial } \\
\text { respiratory chain }\end{array}$ \\
\hline ACAA2 & 3-ketoacyl-CoA thiolase, mitochondrial & 1.2 & Fatty acid metabolic processes \\
\hline NDUFA7 & $\begin{array}{l}\text { NADH dehydrogenase [ubiquinone] } 1 \text { alpha subcomplex } \\
\text { subunit } 7\end{array}$ & 1.20 & $\begin{array}{l}\text { Protein of the complex, that forms the mitochondrial } \\
\text { respiratory chain }\end{array}$ \\
\hline B2M & Beta-2-microglobulin & 1.20 & Component of MHC class I \\
\hline CPT1B & $\begin{array}{l}\text { Isoform } 2 \text { of Carnitine 0-palmitoyltransferase 1, muscle } \\
\text { isoform }\end{array}$ & 1.18 & $\begin{array}{l}\text { Control the long-chain fatty acid beta-oxidation pathway } \\
\text { in muscle mitochondria }\end{array}$ \\
\hline CRAT1 & Isoform 3 of Carnitine 0-acetyltransferase & 1.18 & $\begin{array}{l}\text { Catalyses the transfer of acyl groups from an acyl-CoA } \\
\text { thioester to carnitine }\end{array}$ \\
\hline ATPA & ATP synthase subunit alpha, mitochondrial & 1.17 & ATP synthesis \\
\hline NDUFA2 & $\begin{array}{l}\text { NADH dehydrogenase [ubiquinone] } 1 \text { alpha subcomplex } \\
\text { subunit } 2\end{array}$ & 1.16 & $\begin{array}{l}\text { Protein of the complex, that forms the mitochondrial } \\
\text { respiratory chain }\end{array}$ \\
\hline ACAT1 & Acetyl-CoA acetyltransferase, mitochondrial & 1.15 & Lipid metabolism, b-oxidation \\
\hline IGHG1 & Ig gamma- 1 chain $\mathrm{C}$ region & 1.14 & Immune response \\
\hline DNAJA3 & $\begin{array}{l}\text { Isoform } 2 \text { of DnaJ homolog subfamily A member } 3 \text {, } \\
\text { mitochondrial }\end{array}$ & 1.12 & Modulates apoptotic signal transduction \\
\hline PRDX5 & $\begin{array}{l}\text { Isoform cytoplasmic and peroxisomal of Peroxiredoxin- } \\
5 \text {, mitochondrial }\end{array}$ & 1.12 & $\begin{array}{l}\text { Thiol-specific peroxidase, protective role against } \\
\text { oxidative stress }\end{array}$ \\
\hline EFTU & Elongation factor Tu, mitochondrial & 1.10 & Protein translation in mitochondria \\
\hline HEBP2 & Heme-binding protein 2 & -1.13 & $\begin{array}{l}\text { Promote mitochondrial permeability and necrotic cell } \\
\text { death in stress conditions }\end{array}$ \\
\hline OTUB1 & Ubiquitin thioesterase & -1.14 & Cleaves ubiquitin from branched poly-ubiquitin chains \\
\hline PROB1 & Proline-rich basic protein 1 & -1.25 & Unknown \\
\hline
\end{tabular}

Fold change after 2 years program in comparison to the base level. $p<0.05$.

\section{Correlation analysis between clinical outcome measures and results of proteomic analysis}

Further IPA analysis revealed that several disease and function annotations predicted to be altered after the exercise program (Table 5). Most importantly, the HEPA program seemed to be associated with changes that predicted increased ATP production, another indication of elevated mitochondrial activity. ATP is essential for contractility of the skeletal muscles and also contractility was predicted to be upregulated, and this was significant in the biopsies taken after one year of HEPA but not after two years. Furthermore, the HEPA program was associated with protein changes that predicted reduced fibrosis after one year of HEPA and decreased muscle cell death after both one and two years of HEPA (Table 5). 
Table 5

Disease and function annotations for the proteomic profiles after one or two years of HEPA program.

\begin{tabular}{|llllll|}
\hline Functions & Prediction & z-score year 1 & z-score year 2 & p-value year 1 & p-value year 2 \\
\hline Contractility of muscle & Increased & 2.11 & 1.863 & $1.28 \mathrm{E}-21$ & $2.04 \mathrm{E}-22$ \\
\hline Transport of lipid & Increased & 2.248 & 2.135 & $1.44 \mathrm{E}-05$ & $1.47 \mathrm{E}-05$ \\
\hline Esterification of lipid & Increased & 2.675 & 2.675 & $3.10 \mathrm{E}-05$ & $3.14 \mathrm{E}-05$ \\
\hline Concentration of ATP & Increased & 2.189 & 2.162 & $1.10 \mathrm{E}-07$ & $1.20 \mathrm{E}-07$ \\
\hline Synthesis of (purine) nucleotide & Increased & 3.534 & 3.649 & $3.19 \mathrm{E}-05$ & $3.28 \mathrm{E}-05$ \\
\hline Metabolism of nucleotide & Increased & 3.534 & 3.649 & $3.07 \mathrm{E}-13$ & $3.25 \mathrm{E}-13$ \\
\hline Fibrosis & Decreased & -2.613 & -1.622 & $5.06 \mathrm{E}-11$ & $5.32 \mathrm{E}-11$ \\
\hline Organ degeneration & Decreased & -2.119 & -2.525 & $1.43 \mathrm{E}-05$ & $1.48 \mathrm{E}-05$ \\
\hline Hypertrophy & Decreased & -2.781 & -2.376 & $1.95 \mathrm{E}-11$ & $2.05 \mathrm{E}-11$ \\
\hline Organization of actin cytoskeleton & Decreased & -2.422 & -2.422 & $7.84 \mathrm{E}-09$ & $8.10 \mathrm{E}-09$ \\
\hline Cell death of muscle cells & Decreased & -3.541 & -3.783 & $1.07 \mathrm{E}-10$ & $1.11 \mathrm{E}-10$ \\
\hline Apoptosis of muscle cells & Decreased & -2.785 & -3.76 & $5.27 \mathrm{E}-08$ & $5.42 \mathrm{E}-08$ \\
\hline Necrosis of muscle & Decreased & -3.111 & -3.346 & $8.46 \mathrm{E}-12$ & $8.83 \mathrm{E}-12$ \\
\hline
\end{tabular}

The p-value indicates the significance of the results while the absolute z-score needs be 2 or higher to detect a relevant effect on this function. Data were retrieved from Ingenuity Pathway Analysis.

Significant negative correlations were revealed between PPTs and mitochondrial proteins at one-year follow-up (Table 6).

Table 6

Correlation analysis between clinical data and significantly altered proteins in muscle tissues after one year of training with HEPA program.

\begin{tabular}{|llllllllll|}
\hline & COX7C & \multicolumn{3}{c}{ COX8A } & NDUFS7 & \multicolumn{3}{c|}{ CPT1B } \\
& $\mathrm{p}$ & Rho & $\mathrm{p}$ & Rho & $\mathrm{p}$ & Rho & $\mathrm{p}$ & Rho \\
\hline PPT mean, kPa & 0.031 & -0.700 & 0.029 & -0.657 & 0.018 & -0.713 & 0.023 & -0.685 \\
\hline SPPS 4/10 mean, kPa & 0.034 & -0.636 & 0.041 & -0.615 & 0.034 & -0.636 & 0.021 & -0.692 \\
SPPS 7/10 mean, kPa & 0.019 & -0.706 & 0.026 & -0.671 & 0.026 & -0.671 & 0.014 & -0.734 \\
\hline
\end{tabular}

PLS-DA of data from baseline and year one resulted in a model where principal components PC1 and PC2 combined described $57 \%$ of the variation in data. The model was not significant (CV-ANOVA $p>0.05$ ) and could not be used to predict before/after training status based on the protein profile. The same approach was used when comparing baseline and the second biopsy after two years (PLS-DA: R2X(PC1 + PC2) $=67 \%$, CV-ANOVA > 0.05). Prediction by the model might be improved after variable selection. However, the aim with this study was not to obtain a robust prediction model. Instead this model was used to select possible variables for further investigation. Variables with VIP (variable importance in the projection) above 1.0 were selected and subjected to pathway analysis. IPA demonstrated that proteins influencing separation between the sample groups in the PLS-DA model were related to organ inflammation, which was predicted to decrease $(z-s c o r e=-2.082, p=4.62 E-$ 04 at year two).

\section{Discussion}

In the current subsample of a two-year intervention with HEPA aimed to promote HEPA in sedentary individuals with RA, we applied unbiased proteomics analysis of repeated muscle biopsies before and after one and two years. Although the physical activity was modest and decreased between the first and second year, the effects on muscle proteome, e.g. on proteins involved in the mitochondrial respiratory chain and oxidative phosphorylation, were consistent suggesting a positive metabolic effect in muscle tissue of the long-term HEPA program. 
Similar effects with enrichment of proteins in the mitochondrial compartment, which include the electron transport chain have been reported from short-term training programs in healthy men ${ }^{29-30}$. The respiratory chain is fundamental for ATP production that is necessary to meet the energetic requirements of the muscle cells ${ }^{30}$. In healthy subjects who participated in those studies the muscle homeostasis improved and their capacity to supply ATP increased. Our findings suggest that muscles in people with RA are capable of improving their mitochondrial function in a similar fashion as seen in healthy young men. In myositis, where the main pathological processes occur in the skeletal muscle, mRNA expression patterns after endurance training demonstrated up-regulation of genes involved in capillary growth, which has been associated with increased capillary density in muscle tissue ${ }^{10}$. We did not find a significant increase in the capillary density in the current study, which could be explained by the low number of participants in our study, although there was a tendency of higher number of CD31 positive endothelial cell per area after two years of HEPA.

Our MS-based proteomics results acquired from muscle tissue proteome demonstrate a significant up-regulation of several proteins in the mitochondrial respiratory chain: after one year of HEPA, four out of eight (COX7C, COX8A, NDUFS7, IDH3B) and after two years eight out of 21 (CX6B1, NDUFA4, CYC1, NDUA9, NDUA7, ATPA, NDUA2, ACAA2). This data corroborates predicted increased levels of ATP ( $p=1,10 E-07$ and $p=$ 1,20E-07 for year one and two HEPA, respectively), which synthesis requires augmented electron transport to create a longer lasting electrochemical gradient ${ }^{31}$. On a protein level we observed a $17 \%$ up-regulation of ATP synthase alpha $(p<0,05)$, and at the same time, in five participants out of six a decreased level of IF1 was detected. IF1 inhibits the hydrolase activity of ATP synthase and increased expression of IF1 in tumours promotes the metabolic switch in cancer cells limiting the level of oxidative phosphorylation and promotes glycolysis ${ }^{32}$. In human skeletal muscle of obese patients with type 2 diabetes, the impairments in the balance between mitochondrial ATP-synthase and increased expression of IF1 lead to alterations in lipid metabolism and induction of proinflammatory cytokine TNF-alpha ${ }^{33}$. As seen in Table 5 physical activity in our participants lead to elevated levels of mitochondrial proteins that may increase ATP production improving lipid metabolism and decreasing cell death in muscle tissue. In combination with improved muscle strength these processes could prevent loss of function and muscle mass, moreover they are able to reverse the effects of rheumatoid cachexia ${ }^{34}$.

Surprisingly, we found a negative correlation between four mitochondrial proteins and pressure pain sensitivity at one-year follow-up (Table 6). Therefore, our results do not support the hypothesis that improved mitochondrial respiratory capacity and decreased lipid accumulation in the muscle tissues due to physical activity lead to decreased pain sensitivity. On the other hand, our results tally the previous study that demonstrated that, in people with RA, the HEPA program improved clinical outcome and decreased global pain intensity, but had no positive effect on pain sensitivity ${ }^{16}$.

Multivariate analysis followed by IPA demonstrated that proteins influencing separation between the sample groups in the PLS-DA model were related to organ inflammation, which was predicted to decrease $(\mathrm{p}=4.62 \mathrm{E}-04$ at year two). Serum levels of C-reactive protein (CRP) in our investigated patient group were generally low (Table 1) and probably reflecting ongoing immunosuppressive treatment and low disease activity and did not change during the intervention. Beneficial effects of physical activity on inflammation and possible mechanisms of anti-

inflammatory effects of exercise have been reported in other studies and one suggested explanation being by reduction in body fat ${ }^{35-36}$. The improved fatty acid metabolism and enhanced ATP production due to changes in the mitochondrial machinery demonstrated in our work might also contribute to the anti-inflammatory effect of physical activity.

Our study has clear limitations such as the small sample size and decreased physical activity during the second year. We therefore consider our study as exploratory and further validations of the results are needed. However, the proteomic analysis was performed in repeated muscle biopsies allowing us to follow the molecular changes in muscle for each participant thus eliminating the problem with inter-individual variations.

\section{Conclusions}

Our results indicate that long-term HEPA in people with RA up-regulates proteins in the mitochondrial respiratory chain predicting increased ATP production and muscle contractility. In addition, results indicated that HEPA applied to people with RA may have positive impacts on muscle tissues by decreasing muscle cell death.

\section{List Of Abbreviations}

\section{List of abbreviations}

ACN Acetonitrile

ACPA Anti-Citrullinated Protein/Peptide Antibodies

ACR American College of Rheumatology

AGC Automatic gain control 
ATP Adenosine triphosphate

BCA Bicinchoninic acid assay

BMI Body mass index

CRP C-reactive protein

DAS 28 Desease Activity Score 28 joints

DMSO Dimethyl sulfoxide

DTT Dithiotreitol

FA Formic acid

FDR False discovery rate

FTMS Fourier Transform Mass Spectrometry

HCD Higher-energy collisional dissociation

HEPES 4-(2-hydroxyethyl)-1-piperazineethanesulfonic acid

HEPA Health-enhancing physical activity

IPA Ingenuity Pathway Analysis

K Lysine

LC-MS/MS Liquid chromatography-mass spectrometry (tandem mass spectrometry)

M Methionine

MVC Maximum Voluntary Contraction force

PARA 2010 Physical Activity in Rheumatoid Arthritis 2010

PBS Phosphate-buffered saline

ppm part-per-million

PPT Pressure pain threshold

RA Rheumatoid Arthritis

RF Rheumatoid factor

RM Repetition maximum

RSLC Rapid separation liquid chromatography

SCT Social Cognitive Theory

SDS Sodium dodecyl sulphate

SRQ Swedish Rheumatology Quality register

TST Timed-Stands Test

TTM Transtheoretical Model

WHO World Health Organization

\section{Declarations}


Ethics approval and consent to participate

For current study the ethical approval was obtained from Stockholm Regional Research Ethics Committee (2010/1232-31/1). Each participant gave written informed consent to participate in the study.

\section{Consent for publication}

Not applicable.

\section{Availability of data and materials}

The datasets used in the current study are available from the corresponding author on reasonable request.

\section{Competing interests}

The authors declare no conflicts of interests.

\section{Funding}

This work was supported by AFA insurance No 100172, the Swedish Research Council, Forte Foundation, Combine Sweden, the Swedish Rheumatism Foundation, the Norrbacka Eugenia foundation, the Strategic Research Program in Health Care Science, and the National Doctoral School of Health Care Sciences at Karolinska Institutet, Stockholm County Council (ALF project).

\section{Authors contribution}

$\mathrm{CF}, \mathrm{EK}, \mathrm{BN}, \mathrm{CHO}, \mathrm{YT}$, IEL: study design, collection of muscle biopsies, collection of clinical data, statistical analysis, data interpretation, manuscript writing. EO, JV, HI, MK, CM, PJJ: proteomic analysis, statistical analysis, pathway analysis, IHC, multivariate analysis, data interpretation, manuscript writing.

\section{Acknowledgements}

We wish to thank Dr. Johanna Lanner for valuable input on the manuscript, Eva Lindroos and Cecilia Wick for handling of muscle biopsies and Lena Jonsson for technical assistance at biopsy sampling.

\section{References}

1. Lundberg IE, Nader GA. Molecular effects of exercise in patients with inflammatory rheumatic disease. Nat Clin Pract Rheumatol. 2008 Nov; 4(11):597-604.

2. Stavropoulos-Kalinoglou A, Metsios GS, Veldhuijzen van Zanten JJ, Nightingale P, Kitas GD, Koutedakis Y. Individualised aerobic and resistance exercise training improves cardiorespiratory fitness and reduces cardiovascular risk in patients with rheumatoid arthritis. Ann Rheum Dis. 2013 Nov; 72(11):1819-1825.

3. Metsios GS, Stavropoulos-Kalinoglou A, Veldhuijzen van Zanten JJ, Nightingale P, Sandoo A, Dimitroulas T, et al. Individualised exercise improves endothelial function in patients with rheumatoid arthritis. Ann Rheum Dis. 2014 Apr; 73(4):748-751.

4. Nelson ME, Rejeski WJ, Blair SN, Duncan PW, Judge JO, King AC, et al. Physical activity and public health in older adults: recommendation from the American College of Sports Medicine and the American Heart Association. Med Sci Sports Exerc. 2007 Aug; 39(8):1435-1445.

5. WHO. Global Recommendations on Physical Activity for Health. . Geneva: WHO Press, 2010.

6. van den Berg MH, Ronday HK, Peeters AJ, le Cessie S, van der Giesen FJ, Breedveld FC, et al. Using internet technology to deliver a homebased physical activity intervention for patients with rheumatoid arthritis: A randomized controlled trial. Arthritis Rheum. 2006 Dec 15; 55(6):935-945.

7. Brodin N, Eurenius E, Jensen I, Nisell R, Opava $\mathrm{CH}$. Coaching patients with early rheumatoid arthritis to healthy physical activity: a multicenter, randomized, controlled study. Arthritis Rheum. 2008 Mar 15; 59(3):325-331.

8. Huffman KM, Jessee R, Andonian B, Davis BN, Narowski R, Huebner JL, et al. Molecular alterations in skeletal muscle in rheumatoid arthritis are related to disease activity, physical inactivity, and disability. Arthritis Res Ther. 2017 Jan 23; 19(1):12.

9. Steinz MM, Persson M, Aresh B, Olsson K, Cheng AJ, Ahlstrand E, et al. Oxidative hotspots on actin promote skeletal muscle weakness in rheumatoid arthritis. JCl Insight. 2019 Mar 28; 5.

10. Munters LA, Loell I, Ossipova E, Raouf J, Dastmalchi M, Lindroos E, et al. Endurance Exercise Improves Molecular Pathways of Aerobic Metabolism in Patients With Myositis. Arthritis Rheumatol. 2016 Jul; 68(7):1738-1750. 
11. Nordgren B, Friden C, Demmelmaier I, Bergstrom G, Opava CH. Long-term health-enhancing physical activity in rheumatoid arthritis-the PARA 2010 study. BMC Public Health. 2012 Jun 1; 12:397.

12. Nordgren B, Friden C, Demmelmaier I, Bergstrom G, Lundberg IE, Dufour AB, et al. An outsourced health-enhancing physical activity programme for people with rheumatoid arthritis: exploration of adherence and response. Rheumatology (Oxford). 2015 Jun; 54(6):10651073.

13. Nordgren B, Friden C, Demmelmaier I, Bergstrom G, Lundberg IE, Nessen T, et al. An Outsourced Health-enhancing Physical Activity Program for People with Rheumatoid Arthritis: Study of the Maintenance Phase. J Rheumatol. 2018 Aug; 45(8):1093-1100.

14. Sarajlic P, Friden C, Lund LH, Manouras A, Venkateshvaran A, Larsson SC, et al. Enhanced ventricular-arterial coupling during a 2-year physical activity programme in patients with rheumatoid arthritis: a prospective substudy of the physical activity in rheumatoid arthritis 2010 trial. J Intern Med. 2018 Dec; 284(6):664-673.

15. Venkateshvaran A, Sarajlic P, Lund LH, Friden C, Nordgren B, Opava CH, et al. Impaired left atrial dynamics and its improvement by guided physical activity reveal left atrial strain as a novel early indicator of reversible cardiac dysfunction in rheumatoid arthritis. Eur $\mathrm{J}$ Prev Cardiol. 2018 Jul; 25(10):1106-1108.

16. Lofgren M, Opava CH, Demmelmaier I, Friden C, Lundberg IE, Nordgren B, et al. Long-term, health-enhancing physical activity is associated with reduction of pain but not pain sensitivity or improved exercise-induced hypoalgesia in persons with rheumatoid arthritis. Arthritis Res Ther. 2018 Nov 26; 20(1):262.

17. Bandura A. Social cognitive theory: an agentic perspective. Annu Rev Psychol. 2001; 52:1-26.

18. Prochaska JO, Velicer WF. The transtheoretical model of health behavior change. Am J Health Promot. 1997 Sep-0ct; 12(1):38-48.

19. Prevoo ML, van 't Hof MA, Kuper HH, van Leeuwen MA, van de Putte LB, van Riel PL. Modified disease activity scores that include twentyeight-joint counts. Development and validation in a prospective longitudinal study of patients with rheumatoid arthritis. Arthritis Rheum. 1995 Jan; 38(1):44-48.

20. Hurst NP, Kind P, Ruta D, Hunter M, Stubbings A. Measuring health-related quality of life in rheumatoid arthritis: validity, responsiveness and reliability of EuroQol (EQ-5D). Br J Rheumatol. 1997 May; 36(5):551-559.

21. Astrand PO, Ryhming I. A nomogram for calculation of aerobic capacity (physical fitness) from pulse rate during sub-maximal work. J Appl Physiol. 1954 Sep; 7(2):218-221.

22. Csuka M, McCarty DJ. Simple method for measurement of lower extremity muscle strength. Am J Med. 1985 Jan; 78(1):77-81.

23. Nordenskiold UM, Grimby G. Grip force in patients with rheumatoid arthritis and fibromyalgia and in healthy subjects. A study with the Grippit instrument. Scand J Rheumatol. 1993; 22(1):14-19.

24. Friden C, Thoors U, Glenmark B, Kosek E, Nordmark B, Lundberg IE, et al. Higher pain sensitivity and lower muscle strength in postmenonpausal women with early rheumatoid arthritis compared with age-matched healthy women-a pilot study. Disabil Rehabil. 2013 Aug; 35(16):1350-1356.

25. Shiffman S, Stone AA, Hufford MR. Ecological momentary assessment. Annu Rev Clin Psychol. 2008; 4:1-32.

26. Dorph C, Nennesmo I, Lundberg IE. Percutaneous conchotome muscle biopsy. A useful diagnostic and assessment tool. J Rheumatol. 2001 Jul; 28(7):1591-1599.

27. Wisniewski JR, Zougman A, Nagaraj N, Mann M. Universal sample preparation method for proteome analysis. Nat Methods. 2009 May; 6(5):359-362.

28. Ulfgren AK, Lindblad S, Klareskog L, Andersson J, Andersson U. Detection of cytokine producing cells in the synovial membrane from patients with rheumatoid arthritis. Ann Rheum Dis. 1995 Aug; 54(8):654-661.

29. Holloway KV, O'Gorman M, Woods P, Morton JP, Evans L, Cable NT, et al. Proteomic investigation of changes in human vastus lateralis muscle in response to interval-exercise training. Proteomics. 2009 Nov; 9(22):5155-5174.

30. Egan B, Dowling P, O'Connor PL, Henry M, Meleady P, Zierath JR, et al. 2-D DIGE analysis of the mitochondrial proteome from human skeletal muscle reveals time course-dependent remodelling in response to 14 consecutive days of endurance exercise training. Proteomics. 2011 Apr; 11(8):1413-1428.

31. Walker JE. The ATP synthase: the understood, the uncertain and the unknown. Biochem Soc Trans. 2013 Feb 1; 41 (1):1-16.

32. Sanchez-Cenizo L, Formentini L, Aldea M, Ortega AD, Garcia-Huerta P, Sanchez-Arago M, et al. Up-regulation of the ATPase inhibitory factor 1 (IF1) of the mitochondrial H+-ATP synthase in human tumors mediates the metabolic shift of cancer cells to a Warburg phenotype. J Biol Chem. 2010 Aug 13; 285(33):25308-25313.

33. Formentini L, Ryan AJ, Galvez-Santisteban M, Carter L, Taub P, Lapek JD, Jr., et al. Mitochondrial H(+)-ATP synthase in human skeletal muscle: contribution to dyslipidaemia and insulin resistance. Diabetologia. 2017 Oct; 60(10):2052-2065.

34. Sharif S, Thomas JM, Donley DA, Gilleland DL, Bonner DE, McCrory JL, et al. Resistance exercise reduces skeletal muscle cachexia and improves muscle function in rheumatoid arthritis. Case Rep Med. 2011; 2011:205691. 
35. de Souza DC, Matos VAF, Dos Santos VOA, Medeiros IF, Marinho CSR, Nascimento PRP, et al. Effects of High-Intensity Interval and ModerateIntensity Continuous Exercise on Inflammatory, Leptin, IgA, and Lipid Peroxidation Responses in Obese Males. Front Physiol. 2018 ; 9:567.

36. Pedersen LR, Olsen RH, Anholm C, Astrup A, Eugen-Olsen J, Fenger M, et al. Effects of 1 year of exercise training versus combined exercise training and weight loss on body composition, low-grade inflammation and lipids in overweight patients with coronary artery disease: a randomized trial. Cardiovasc Diabetol. 2019 Oct 1; 18(1):127.

\section{Figures}

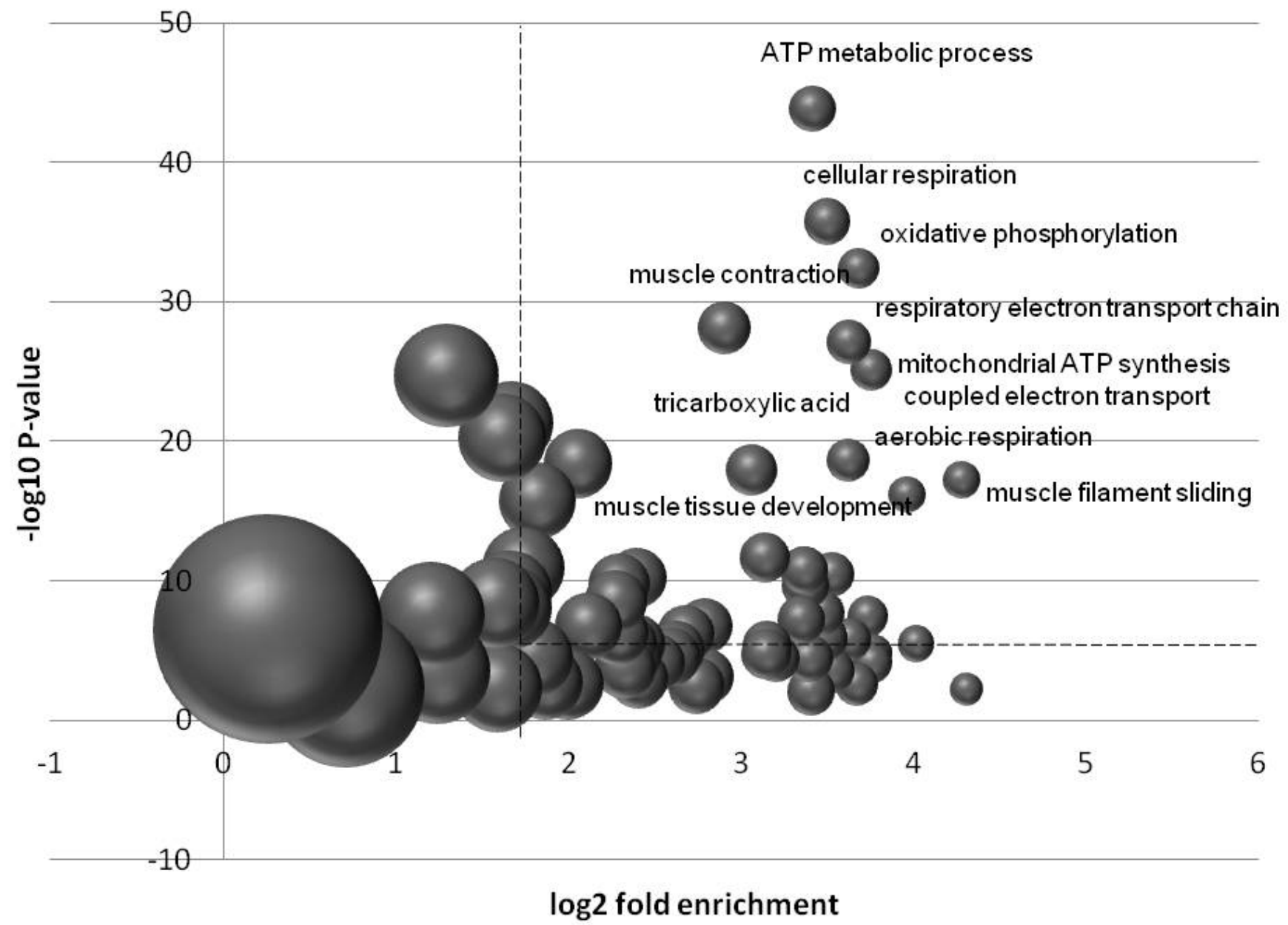

Figure 1

Biological processes overrepresented in the muscle proteome after training period in RA patients. The size of the circles corresponds to number of genes associated with the biological process. Cut-off levels are limited by dash lines.

\section{Supplementary Files}

This is a list of supplementary files associated with this preprint. Click to download.

- SupplementaryFiguresPARA.docx 